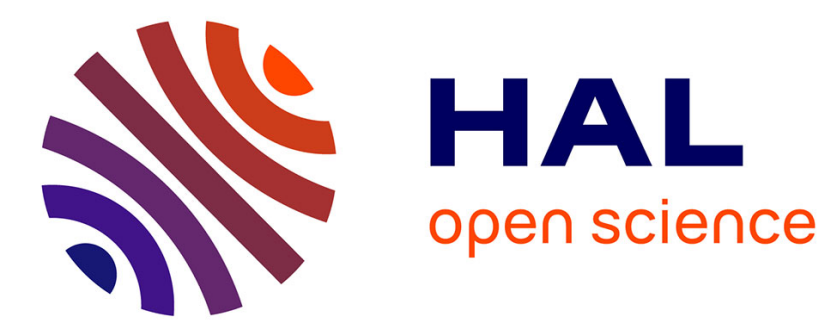

\title{
Earnings distribution among Spanish engineers : research vs. non-research occupations
}

Gérard Lassibille

\section{To cite this version:}

Gérard Lassibille. Earnings distribution among Spanish engineers : research vs. non-research occupations. Research Policy, 2001, 30 (4), pp.673-680. 10.1016/S0048-7333(00)00097-4 . halshs-01266324

\section{HAL Id: halshs-01266324 \\ https://shs.hal.science/halshs-01266324}

Submitted on 7 Jun 2021

HAL is a multi-disciplinary open access archive for the deposit and dissemination of scientific research documents, whether they are published or not. The documents may come from teaching and research institutions in France or abroad, or from public or private research centers.
L'archive ouverte pluridisciplinaire HAL, est destinée au dépôt et à la diffusion de documents scientifiques de niveau recherche, publiés ou non, émanant des établissements d'enseignement et de recherche français ou étrangers, des laboratoires publics ou privés. 


\title{
Earnings distribution among Spanish engineers: research vs. non-research occupations
}

\author{
Gérard LASSIBILLE \\ IREDU-CNRS \\ Université de Bourgogne
}

Article publié dans Research policy, 30, 2001, p.673-680

\begin{abstract}
:
Based on individual survey data, we estimate separate earnings equations for engineers who hold a research occupation and engineers who work in other fields using a switching regression model. From these results, we compare the wage-generating process for each subgroup and evaluate the overall wage gaps across the working life of each category of engineers. On average, researchers receive lower wages compared to their peers. However, the estimation of the earnings models indicate that, holding everything else constant, engineers holding research positions have higher salaries at the beginning of their working life. Due to the recent growth of R\& D activities in Spain, we explain these earnings gap by a transitory cohort effect. However, in this new context, we do not exclude that this differential might reflect also a deep change in the working conditions that private sector firms offer to scientists.
\end{abstract}

\section{Introduction}

Economic literature has devoted numerous studies to career choice decision of engineers and scientists, and to their earnings and turnover over the lifecycle (see, e.g., Park and Bielfeld, 1976; Azevedo, 1977; Cooke, 1980; Wilson, 1980; Biddle and Roberts, 1994; Ferrall, 1995; Lavoie and Finnie, 1998; Trem- blay et al., 1998).

Due to the lack of appropriate data, there is no such study for Spain. This article attempts to fill this gap by analyzing the wages of engineers who hold research and non-research positions in private sector firms. Based on survey data conducted by a Spanish professional association of engineers, we estimate separate earnings functions for both categories of engineers using a switching regression model. From these estimations, we compare the underlying wage-generating process for each category of engineers and evaluate their experience-earnings profiles over their working life. Results show that researchers receive, on average, lower wages compared to their counterparts. However, the regression results indicate that, all else remaining the same, engineers in research path have higher salaries at the beginning of their working life than their peers. We explain this wage gap by the scarcity of new entrants in the labor market for scientists, and thus by a transitory cohort effect. However, given the recent growth of R\& D activities in Spanish private sector firms, we do not exclude that this differential might reflect a deep change in the working conditions that business firms offer to scientists.

The paper proceeds in the following manner. Section 1 presents briefly the data and the characteristics of engineers who hold research and non-research positions. Section 2 describes the methodological approach we use to estimate the wage gaps between the two categories of engineers. Section 3 presents the empirical results. 


\section{The data}

Empirical results are based on data from a postal survey conducted by the Professional Association of Industrial Engineers in Catalonia (see Enginyers Industrials de Catalunya, Associació/Col-legi, 1991, 1992). The survey was administered to all male engineers working in the region; among those, about $30 \%$ answered the questionnaire. ${ }^{1}$ These cross-sectional data contain valuable information for the analysis attempted here. They detail the main activity and the job of each individual at the time the survey was conducted. They describe also their professional experience, their wages, and their level of responsibility within the firm. Apart from these personal characteristics, the survey gives also information on the firm where the individuals work (sector, size, national/multinational capital controlled firms). Note that the survey does not report any information on the educational background of respondents. This is because all Spanish engineers receive similar train-ing.

Table 1

Characteristics of engineers by type of occupation ${ }^{a}$

\begin{tabular}{lcc}
\hline & \multicolumn{2}{c}{ Engineers holding } \\
\cline { 2 - 3 } & $\begin{array}{c}\text { A research } \\
\text { occupation }\end{array}$ & $\begin{array}{c}\text { A non-research } \\
\text { occupation }\end{array}$ \\
\hline In wages & 8.72 & 8.96 \\
Experience (years) & 12.07 & 16.35 \\
Level of responsibility (\%) & & \\
Level 1 & 26.06 & 49.52 \\
Level 2 & 36.36 & 25.05 \\
Level 3 & 21.21 & 15.47 \\
Level 4 & 16.36 & 9.96 \\
Working for a multinational & 42.42 & 43.06 \\
company (\%) & & \\
& & \\
Size of firm (\%) & & \\
Less than 50 employees & 13.94 & 18.36 \\
Between 50 and 499 employees & 24.85 & 33.18 \\
500 employees and more & 61.21 & 48.46 \\
Sector of activity (\%) & & \\
Food & & \\
Textile, wood, paper & 1.21 & 3.69 \\
Electrical & 4.24 & 6.01 \\
Chemical & 28.48 & 17.52 \\
Metals and manufacturing & 6.67 & 16.19 \\
Services & 40.00 & 32.92 \\
Number of observations & 18.79 & 23.45 \\
\hline & 165 & 2631 \\
\hline
\end{tabular}

${ }^{a}$ Levels of responsibility are arranged in descending order.

1 As is usual in postal surveys, this response rate is low. Although we are not able to evaluate the bias induced by such a response rate, if we compare the characteristics of the sample with keys aspects of the distribution of R\&D activities in Spain (see below), it seems that this bias is probably small. 
After completing secondary education, they enroll in Escuelas Tecnicas Superiores ${ }^{2}$ (5 years of higher education) which award all the same kinds of degrees. Differences in the quality of schools and students in such a non-differentiated system might theoretically exist. This said, in Spain, these differences are probably small, because the number of schools is very limited ${ }^{3}$ and candidates for a place in an engineering school are highly selected.

In order to obtain more observations, we used data from both the 1991 and 1992 surveys. For individuals who responded to both surveys, only the 1992 questionnaire was used. The selected sample is restricted to individuals who are working full time. Self-employed engineers as well as engineers working in the public sector are excluded from the analysis. After deleting missing values, these exclusions left us with about 2700 observations.

Table 1 presents selected statistics for the sample of engineers who hold research and non-research occupations (management, production, project). In this table, wages refer to annual labor earnings and are not defined by the hourly wage rates, because hours of work are not identified in the survey. The results show that engineers in non-research occupations receive, on average, higher wages compared to their counterparts; the earnings gap between both categories is about $20 \%$. Researchers have about 4 years less professional experience than others. On average, engineers working in research occupations have less responsibility than their peers: $26 \%$ compared to $50 \%$ is assigned to the highest job level (level 1); 16\% holds occupations which entail no supervision of other engineers (level 4) compared to only $10 \%$ for their counterparts. They are working more frequently in very large business firms (61\% vs. 48\%). Finally, engineers in research occupations are shown to work mainly in the electrical and manufacturing sectors, i.e. in high technology industries. These observations are in line with more general findings on the distribution of $R \& D$ activities in Spain (see Instituto Nacional de Estadística, 1993).

\section{The conceptual framework}

To evaluate earnings gaps between both categories of engineers, we follow the tradition by postulating a switching regression model (see, e.g., Lee, 1978; Maddala, 1983). Let us denote the research and non-research occupations as occupations 1 and 2, respectively, and express the corresponding wage equations as:

$$
\begin{aligned}
& \ln w_{1}=X \beta_{1}+u_{1}, \\
& \ln w_{2}=X \beta_{2}+u_{2},
\end{aligned}
$$

where $w$ stands for annual labor earnings, $X$ is a vector of characteristics, $\beta_{l}$ is a parameter vector, and $u_{1}$ is the random error term.

We assume that the expected benefits to the engineer are equal, or proportional to the differences in the wage rates between the two occupations. Thus, an individual will work in a research occupation if :

$$
\left(\ln w_{1}-\ln w_{2}\right)>Z_{1} \gamma_{1}+\varepsilon_{1},
$$

where $\mathrm{Z}$ is a vector of explanatory variables associated with the probability of holding a research job, $\gamma$ is a parameter vector, and $\varepsilon$ is an error term.

2 ETS/Engineering Schools.

3 In some fields, e.g., like aeronautics, there is only one engineering school in the whole country. 
Substituting Eqs. 1 and 2 into Eq. 3 and combining terms yields:

$$
\begin{aligned}
& I^{*}=Z \gamma+\varepsilon \\
& I=1 \text { (research occupation), if } I^{*} \geq 0 \\
& I=0 \text { (non-research occupation), if } I^{*}<0
\end{aligned}
$$

In this specification, $I^{*}$ is a partially observed dichotomous variable that describes the selection process. We observe the outcome (i.e. wages when holding a research or a non-research occupation) depending on whether $I^{*}$ is positive or negative. This equation summarizes a two-step process. First, the expected wage differential must be large enough for the individual to make it worthwhile to try to obtain a research job. The choice to apply is explained by the expected wage gap (net of the cost of applying for the job) and variables related to the preference for research occupation. Second, the employer determines whether the person is chosen for the job; explanatory variables are the person's attributes that matter to the employer. For this reason, the factors affecting the selection process (i.e. the vector $\mathrm{Z}$ ) include both supply and demand variables. The switching regression model above is estimated using FIML, under the hypothesis that the three error terms $\left(\mathrm{u}_{1}, \mathrm{u}_{2}, \varepsilon\right)$ follow a trivariate normal distribution with non-zero covariances. While OLS estimations of Eqs. 1 and 2 represent the unconditional wages in the two occupations (i.e. the expected earnings of engineers prior to the job choice process), the switching regression model gives an estimation of the wages conditional upon being selected for a particular occupation. The conditional wages of each category of engineers are given by:

$$
\begin{aligned}
& E\left[\ln w_{1} \mid I^{*} \geq 0\right]=X \beta_{1}+\rho_{I \varepsilon} \sigma_{1} \lambda_{l}, \\
& E\left[\ln w_{2} \mid I^{*} \geq 0\right]=X \beta 2+\rho_{2 \varepsilon} \sigma_{2} \lambda_{2},
\end{aligned}
$$

Where $\gamma_{1}=[\varnothing(Z \gamma) / \Phi(Z \gamma)]$ and $\lambda_{2}=[-\varnothing(Z \gamma) /\{1-\Phi(Z \gamma)\}], \varnothing$ and $\Phi$ being, respectively, the standard normal density and cumulative distribution functions, $\rho_{1 \varepsilon}$ is the covariance between $u_{i}$ and $\varepsilon$, and $\sigma_{i}$ is the variance of $u_{i}$.

\section{The empirical results}

Table 2 displays the estimation results of the switching regression model described above. It shows also the OLS estimations of the wage equations for each category of engineers. The variables included in the occupation choice model and the earnings equations are: professional experience, size of firm, sector of activity and whether the engineer is working for a multinational company. ${ }^{4}$ We discuss the coefficients of these variables only briefly, because for our purpose, the empirical results are best summarised in the earnings profiles presented further on.

4 We exclude this variable from the occupation choice model because engineers are equally distributed in each type of firms (see Table 1). In our model, all variables that affect the selection process are wage determinants. As shown by Olsen (1980), this may increase the sensitivity of the results. However, we find no theoretical reasons to exclude from the wage equation variables included in the occupation choice model. 
Table 2

Earnings equations by type of occupations ${ }^{\mathrm{a}}$

\begin{tabular}{|c|c|c|c|c|c|}
\hline & \multicolumn{2}{|l|}{ OLS } & \multicolumn{3}{|c|}{ Switching regression model } \\
\hline & $\begin{array}{l}\text { Research } \\
\text { occupation }\end{array}$ & $\begin{array}{l}\text { Non-research } \\
\text { occupation }\end{array}$ & $\begin{array}{l}\text { Selection } \\
\text { equation }\end{array}$ & $\begin{array}{l}\text { Research } \\
\text { occupation }\end{array}$ & $\begin{array}{l}\text { Non-research } \\
\text { occupation }\end{array}$ \\
\hline Constant & $\begin{array}{l}8.1215 \\
(113.86)\end{array}$ & $\begin{array}{l}8.1931 \\
(295.69)\end{array}$ & $\begin{array}{l}-0.8961 \\
(7.52)\end{array}$ & $\begin{array}{l}8.1186 \\
(2.44)\end{array}$ & $\begin{array}{l}8.1212 \\
(245.41)\end{array}$ \\
\hline Experience (years) & $\begin{array}{l}0.0797 \\
(8.80)\end{array}$ & $\begin{array}{l}0.0782 \\
(28.66)\end{array}$ & $\begin{array}{l}-0.0425 \\
(8.24)\end{array}$ & $\begin{array}{l}0.0797 \\
(0.99)\end{array}$ & $\begin{array}{l}0.0816 \\
(28.38)\end{array}$ \\
\hline Experience & $\begin{array}{l}-0.0018 \\
(5.89)\end{array}$ & $\begin{array}{l}-0.0015 \\
(19.24)\end{array}$ & - & $\begin{array}{l}-0.0018 \\
(4.63)\end{array}$ & $\begin{array}{l}-0.0015 \\
(21.89)\end{array}$ \\
\hline \multicolumn{6}{|l|}{ Size of firm } \\
\hline Less than 50 employees & $\begin{array}{l}-0.0353 \\
(0.56)\end{array}$ & $\begin{array}{l}-0.0256 \\
(1.28)\end{array}$ & $\begin{array}{l}-0.3896 \\
(3.02)\end{array}$ & $\begin{array}{l}-0.0359 \\
(0.05)\end{array}$ & $\begin{array}{l}-0.0094 \\
(0.44)\end{array}$ \\
\hline Between 50 and 499 employees & $\begin{array}{l}0.0504 \\
(1.04)\end{array}$ & $\begin{array}{l}0.0104 \\
(0.65)\end{array}$ & $\begin{array}{l}-0.2539 \\
(2.63)\end{array}$ & $\begin{array}{l}0.0501 \\
(0.10)\end{array}$ & $\begin{array}{l}0.0209 \\
(1.24)\end{array}$ \\
\hline $\begin{array}{l}\text { Working for a multinational } \\
\text { company }\end{array}$ & $\begin{array}{l}0.0125 \\
(0.29)\end{array}$ & $\begin{array}{l}0.0329 \\
(2.21)\end{array}$ & - & $\begin{array}{l}0.0125 \\
(0.25)\end{array}$ & $\begin{array}{l}0.0319 \\
(2.14)\end{array}$ \\
\hline Sector of activity & & & & & \\
\hline Food & $\begin{array}{l}0.5646 \\
(3.25)\end{array}$ & $\begin{array}{l}-0.0334 \\
(0.84)\end{array}$ & $\begin{array}{l}-1.4074 \\
(5.15)\end{array}$ & $\begin{array}{l}0.5624 \\
(0.20)\end{array}$ & $\begin{array}{l}-0.0196 \\
(0.47)\end{array}$ \\
\hline Textile, wood, paper & $\begin{array}{l}-0.3796 \\
(3.78)\end{array}$ & $\begin{array}{l}-0.0497 \\
(1.53)\end{array}$ & $\begin{array}{l}-0.1860 \\
(1.00)\end{array}$ & $\begin{array}{l}-0.3797 \\
(0.95)\end{array}$ & $\begin{array}{l}-0.0500 \\
(1.66)\end{array}$ \\
\hline Electrical & $\begin{array}{l}0.0690 \\
(1.21)\end{array}$ & $\begin{array}{l}-0.0292 \\
(1.30)\end{array}$ & $\begin{array}{l}0.3866 \\
(3.16)\end{array}$ & $\begin{array}{l}0.0697 \\
(0.09)\end{array}$ & $\begin{array}{l}-0.0446 \\
(1.75)\end{array}$ \\
\hline Chemical & $\begin{array}{l}-0.0788 \\
(0.91)\end{array}$ & $\begin{array}{l}-0.0198 \\
(0.85)\end{array}$ & $\begin{array}{l}-0.1717 \\
(0.96)\end{array}$ & $\begin{array}{l}-0.0791 \\
(0.21)\end{array}$ & $\begin{array}{l}-0.0045 \\
(0.17)\end{array}$ \\
\hline Metals and manufacturing & $\begin{array}{l}0.0272 \\
(0.49)\end{array}$ & $\begin{array}{l}-0.0330 \\
(1.72)\end{array}$ & $\begin{array}{l}0.1562 \\
(1.45)\end{array}$ & $\begin{array}{l}0.0274 \\
(0.09)\end{array}$ & $\begin{array}{l}-0.0413 \\
(2.15)\end{array}$ \\
\hline$\sigma$ & $\begin{array}{l}- \\
-\end{array}$ & $\begin{array}{l}- \\
-\end{array}$ & $\begin{array}{l}- \\
-\end{array}$ & $\begin{array}{l}0.2280 \\
(10.36)\end{array}$ & $\begin{array}{l}0.3681 \\
(69.10)\end{array}$ \\
\hline$\rho$ & $\begin{array}{l}- \\
-\end{array}$ & - & - & $\begin{array}{l}0.1083 \\
(5.01)\end{array}$ & $\begin{array}{l}0.7785 \\
(23.23)\end{array}$ \\
\hline $\begin{array}{l}\text { Log likelihood } \\
R^{2}\end{array}$ & $\overline{0.6180}$ & $\overline{0.3870}$ & $\begin{array}{l}-1440.698 \\
-\end{array}$ & $\begin{array}{l}- \\
-\end{array}$ & $\begin{array}{l}- \\
-\end{array}$ \\
\hline
\end{tabular}

"The $t$-statistics in parentheses.

Results displayed in Table 2 show first that the correlation between the error terms of the earnings equations and that of the selection equation is statistically significant; otherwise, stated OLS estimations of the earnings equations for each category of engineers are biased. ${ }^{5}$

Table 3

Marginal returns to professional experience $(\%)^{\mathrm{a}}$

\begin{tabular}{lllll}
\hline & 1 year & 5 years & 10 years & 15 years \\
\hline $\begin{array}{l}\text { Engineer in research } \\
\text { occupation }\end{array}$ & 7.6 & 6.2 & 4.4 & 2.6 \\
$\begin{array}{l}\text { Engineer in non-research } \\
\text { occupation }\end{array}$ & 7.9 & 6.7 & 5.2 & 3.7 \\
\hline
\end{tabular}

${ }^{\mathrm{a}}$ Based on regression results in Table 2.

In what concerns the choice of occupation, the main noteworthy feature in the results is that, all else remaining the same, the probability of holding a research job declines quite strongly as professional experience increases. Simulations not reported to save space, indicate, e.g., that the probability of holding a research job is around 6\% for an individual who has 5 years of professional experience

5 The bias is larger for engineers holding a non-research job since $\sigma_{1} \rho_{1}$ is much larger than $\sigma_{2} \rho_{2}$. 
and 3\% for 15 years of professional experience. The negative impact of professional experience may arise for several reasons: (a) as shown, e.g., by Biddle and Roberts (1994) or Dasgupta and David (1987), mobility to production or management positions is the natural evolution for many researchers as these positions offer, on average, higher compensations than R\& D occupations; ${ }^{6}$ (b) in Spain, R\&D activities have grown substantially during the last two decades; in this new context, the negative impact of professional experience on the probability of holding a research occupation may only reflect a cohort effect (see the discussion below).

Turning to the earnings equations, results in Table 2 show that, holding everything else constant, the mean earnings of researchers increase more slowly over the life cycle compared to their peers. Depending on the initial level of experience, the marginal returns to professional experience is between $0.3 \%$ and $1.1 \%$ lower for engineers working in research occupations (Table 3 ). According to the human capital theory (see Becker, 1975), a possible reason for such differentiated returns to professional experience is a faster obsolescence of specific human capital in R\& D occupations. We also found that, all else remaining the same, the type of firm a researcher works in makes no significant difference to his earnings. Conversely, engineers in non-research occupations working for a multinational company earn significantly more than their counterparts.

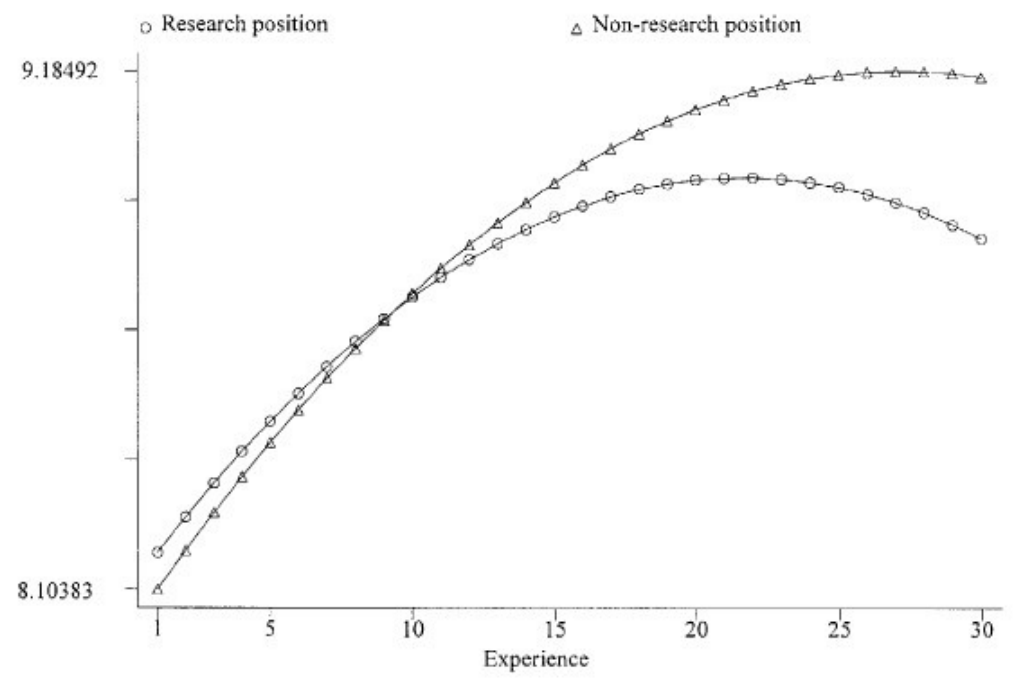

Fig. 1. Experience-earnings profiles by type of occupation.

Using the regression results in Table 2, Fig. 1 shows the experience-wage profiles of both categories of engineers. These profiles refer to conditional wages; they are computed according to formulas 5 and 6 for representative individuals defined at the sample means.

The first noteworthy feature in the results is that starting salaries of researchers exceed slightly those of engineers who hold non-research occupations. The second feature to underline is that after a relatively short period of time (about 10 years), non-research engineers have higher wages compared to their peers, and the earnings gap between the two categories of engineers increases widely over the rest of the life cycle.

A potentially important reason for this pattern has to do with the opportunities of promotion in research and non-research jobs. The survey used in this paper offers some interesting insights on this question as it describes the responsibility level of engineers within their firms. Based on these data, we adjust the probability of holding a certain level of responsibility for each sample of engineers by postulating anordered probit model (see, e.g., Maddala, 1983). Using these regression

6 Due to data limitations, we are not able to analyze the switchfrom a scientific track to a managerial one. 
results, ${ }^{7}$ Table 4 reports the predicted probability of being assigned to various levels of responsibility according to the occupation of the engineers and their professional experience; these predictions are computed in a standard way (see, e.g., Greene, 1997). The results show that, other things being equal, engineers holding research occupations are more likely to be assigned to low levels of responsibility. For example, their probability of getting an executive position (level 1) after 10 years of professional experience is only $19 \%$ compared to $39 \%$ for their peers; at the end of their working life, their probability of holding occupations which entail no supervision of other engineers (level 4) is about three times larger than their non-research counterparts. Clearly, these results suggest that over their working life, researchers have less opportunity to move into better-paid jobs than engineers who hold non-research occupations. This conclusion is in line with other empirical findings (see Beltramo and Paul, 1994). The lower opportunity of promotion in research occupations may be probably explained by the internal organization of R\&D activities, and in particular by a less pyramidal structure of occupations.

Lower career expectations and outcomes in research occupations, which lead many researchers to switch to management or production positions offering better opportunities, may explain the wage gaps we observe at mid-career between both categories ofengineers. However, they do not explain why researchers receive an earnings premium at the beginning of their working life (see Fig. 1). In Spain, it is more likely the changes in the labor market conditions for scientists in recent years (and thus, cohort effects) that seem to explain the wage differentials between the two categories of engineers early on in the working life.

Table 4

Predicted probability of being assigned to different levels of responsibility by type of occupations and professional experience ${ }^{\mathrm{a}}$

\begin{tabular}{lcccc}
\hline & \multicolumn{4}{c}{ Years of professional experience } \\
\cline { 2 - 5 } & 10 & 15 & 20 & 25 \\
\hline Level 1 & 18.7 & 28.5 & 40.3 & 53.1 \\
Research occupations & 39.2 & 47.0 & 55.0 & 62.8 \\
Non-research occupations & & & & \\
Level 2 & & & & \\
Research occupations & 51.7 & 52.0 & 47.8 & 40.3 \\
Non-research occupations & 34.0 & 32.3 & 29.6 & 26.1 \\
Level 3 & & & & \\
Research occupations & 22.5 & 15.9 & 10.1 & 5.9 \\
Non-research occupations & 18.9 & 15.3 & 11.9 & 8.9 \\
Level 4 & & & & \\
Research occupations & 7.1 & 3.6 & 1.7 & 2.2 \\
Non-research occupations & 7.9 & 5.4 & 3.5 & 0.7 \\
\hline
\end{tabular}

${ }^{\mathrm{a}}$ The responsibility levels are arranged in descending order. The predictions are computed at the sample means from an ordered probit model (see Appendix A).

7 See regression results in Appendix A. 
Table 5

Personnel employed in R\&D activities by sector and year (in full time equivalents)

\begin{tabular}{lrrr}
\hline & 1980 & 1990 & Variation (\%) \\
\hline Total personnel & & & \\
Public administration & 11,359 & 17,170 & 51 \\
Higher education & 11,713 & 18,904 & 61 \\
Private sector firms & 12,424 & 28,508 & 129 \\
Total & 35,496 & 64,582 & 82 \\
Scientists and engineers & & & \\
Public administration & 3481 & 7623 & 119 \\
Higher education & 11,900 & 18,904 & 59 \\
Private sector firms & 2932 & 11,006 & 275 \\
Total & 18,323 & 37,534 & 105 \\
\hline
\end{tabular}

Source: Instituto Nacional de Estadística (1993).

As indicated in Table 5 below, R\&D activities in Spanish firms grew rapidly during the 1980s: the total number of research related jobs in enterprises increased by about $130 \%$ and the number of scientists multiplied by almost four. These increases are much larger than those registered in other R\&D sectors. As a matter of fact, in public administration and higher education, the number of workers employed in R\&D activities increased, on average, by only $50 \%$, and the number of scientists doubled at the most.

One consequence of the rapid growth of R\& D activities in the private sector has been a substantial shortage of science-related manpower. ${ }^{8}$ During the decade under consideration, the number of graduates from engineering schools was still small, and as a result, the supply for scientists increased less rapidly than the demand. The gap in earnings early on in the working life between research and non-research en- gineers (see Fig. 1) probably reflects these time-related market conditions and consequently, the relative scarcity of scientists at the beginning of the 1990s. In other words, the earnings premium researchers receive at the early stage of their career is explained partly by cohort effects. The fact that senior engineers holding research positions earn less than their non-research counterparts is in accordance with such an explanation: in the past, R\&D activities in the private sector were relatively scarce and demand for scientists was small compared with the supply. Obviously, the scarcity of R\&D activities in the past explains partly the earnings gap between senior researchers and senior engineers who hold non-research occupations. Part of it is due also to selection issues, as in mid-career, many talented researchers switch to management or production po- sitions offering higher salaries. ${ }^{9}$

\section{Conclusion}

Using a unique data set of engineers working in private sector firms, we focused on wage gaps between engineers holding research and non-research positions. We found that, on average, (i) researchers earn less than their peers; (ii) the rate of returns to professional experience is lower in

8 For an analysis of shortages in the labor market for engineers and scientists, see, e.g., Bosworth (1981), Forbes and Zampelli (1991), Hansen (1967).

9 Only panel data would make it possible to sort out the respective influences of each element in explaining earnings gap between each category of engineer at this stage of their working life. 
R\&D positions; (iii) opportunity of promotion within research occupations is smaller. These results are apparently in line with other empirical findings. However, in the Spanish context, substantial differences do exist. In fact, results from wage models that control for selectivity have shown that the two categories of engineers have different experience-earnings profiles. In particular, we found that at the beginning of their working life, researchers receive higher salaries compared to their counterparts. However, after a short period of time, the wages of engineers working in non-research paths exceed those of researchers. Part of the earnings gap observed at this stage is consistent with the idea that many engineers, and among them probably the most talented, start their careers as researchers and switch to management or production positions offering better-paid jobs.

The fact, that engineers employed in research occupations receive an earnings premium at the early stage of their working life, is apparently in line with the recent development of R\&D activities in Spanish private sector firms; it reflects partly cohort effects and the scarcity of new entrants in the labor market for scientists. It might suggest also a deep change in the work conditions offered to scientists by business firms. Additional analysis is required to explore this issue. However, due to the recent growth of the labor market for scientists, more insight is needed to really sort out the influences on the wage-generating process of researchers of, on one hand, these possible new working conditions and, on the other, of the aforementioned generation effect.

\section{Appendix A}

Estimates of the probability of being assigned to different levels of responsibility by type of occupation.

\begin{tabular}{|c|c|c|c|c|}
\hline & \multicolumn{2}{|c|}{$\begin{array}{l}\text { Engineers holding a research } \\
\text { occupation }\end{array}$} & \multicolumn{2}{|c|}{$\begin{array}{l}\text { Engineers holding a non- } \\
\text { research occupation }\end{array}$} \\
\hline & Coefficient & $t$-statistics & Coefficient & $t$-statistics \\
\hline Experience (years) & -0.0645 & 5.18 & -0.0401 & 0.0028 \\
\hline Working for a multinational company & 0.7806 & 3.81 & 0.1926 & 0.0494 \\
\hline \multicolumn{5}{|l|}{ Size of firm } \\
\hline Less than 50 employees & -1.9267 & 6.09 & -1.6788 & 0.0795 \\
\hline Between 50 and 499 employees & -1.1387 & 4.77 & -1.0353 & 0.0541 \\
\hline \multicolumn{5}{|l|}{ Sector of activity } \\
\hline Food & -1.4093 & 1.61 & -0.1120 & 0.1299 \\
\hline Textile, wood and paper & -0.6444 & 1.37 & -0.1056 & 0.1131 \\
\hline Electrical & 0.1058 & 0.40 & 0.4511 & 0.0737 \\
\hline Chemical & -0.0975 & 0.25 & -0.0293 & 0.0776 \\
\hline Metals and manufacturing & -0.6621 & 2.50 & -0.1553 & 0.0665 \\
\hline$\mu_{1}$ & -2.2241 & 6.86 & -1.2194 & 0.0787 \\
\hline$\mu_{2}$ & -0.7976 & 2.81 & -0.3272 & 0.0762 \\
\hline$\mu_{3}$ & 0.1367 & 0.48 & 0.4640 & 0.0777 \\
\hline Number of observations & 165 & & 2631 & \\
\hline Log likelihood & -171.53 & & -2663.53 & \\
\hline$\chi^{2}(9)$ & 100.27 & & 1056.72 & \\
\hline Pseudo- $R^{2}$ & 0.226 & & 0.166 & \\
\hline
\end{tabular}

Estimates based on the following ordered probit model: $\boldsymbol{Z}=\boldsymbol{X} \boldsymbol{\beta}+\varepsilon$. Where the error term $\varepsilon$ is assumed to be distributed as standard normal, and the observed counterpart of $\boldsymbol{Z}$, noted $Y$, is such as: $Y=I$ if $\mu_{I-1}<\boldsymbol{Z}<\mu_{I}$. 


\section{References}

Azevedo, R., 1977. Scientists, engineers and the reservation wage. Quarterly Review of Economics and Business 17, 41-51.

Becker, G.S., 1975. Human Capital. National Bureau of Economic Research and Columbia University Press, New York.

Bosworth, D., 1981. The demand for qualified scientists and engineers. Applied Economics 13, 411-429.

Beltramo, J.P., Paul, J.J., 1994. Les rémunérations et les carrières des chercheurs en entreprise. Paper presented at the XIII World Congress of Sociology, Bielefeld, 1994.

Biddle, J., Roberts, K., 1994. Private sector scientists and engineers and the transition to management. The Journal of Human Resources 29, 83-107.

Cooke, W., 1980. Turnover and earnings: the scientist and engineer case. The Journal of Human Resources 15, 435-443.

Dasgupta, P., David, P., 1987. Information disclosure and the economics of science and technology. In: Feiwel, G.R. (Ed.), Arrow and the Ascent of Modern Economic Theory. New York University Press, New York, pp. 519-542.

Enginyers Industrials de Catalunya, Associació/Col-legi, 1991. Salaris 1991, September.

Enginyers Industrials de Catalunya, Associació/Col-legi, 1992. Salaris 1992, September.

Ferrall, C., 1995. Levels of responsibility in jobs and the distribution of earnings among US engineers, 1961-1986. Industrial and Labor Relations Review 39, 150-169.

Forbes, K., Zampelli, E., 1991. Growth, technology and the demand for scientists and engineers. Industrial Relations 30, 294-301.

Greene, W., 1997. Econometric Analysis. Prentice-Hall, London. Hansen, L.W., 1967. The economics of scientific and engineering manpower. The Journal of Human Resources 2, 191-215.

Instituto Nacional de Estadística, 1993. Estadística sobre las Actividades en Investigación Científica y Desarrollo Tecnológico, Madrid, 990.

Lavoie, M., Finnie, R., 1998. The occupational dynamics of recent Canadian engineering graduates inside and outside the bounds of technology. Research Policy 27, 143-158.

Lee, L.F., 1978. Unionism and wage rates: a simultaneous equation model with qualitative and limited dependent variables. International Economic Review 19, 415-433.

Maddala, G.S., 1983. Limited Dependent and Qualitative Variables in Econometrics. Cambridge Univ. Press, Cambridge.

Olsen, R.J., 1980. A least squares correction for selectivity bias. Econometrica 48 (7), 1815-1820.

Park, S.H., Bielfeld, J., 1976. The effect of schooling, postschool investments, and unemployment on the earnings of engineers: a human capital approach. Quarterly Review of Economics and Business 16, 45-50.

Tremblay, M., Wils, T., Proulx, C., 1998. Determinants of Desired Career Paths among Canadian Engineers. Mimeo, CIRANO.

Wilson, R., 1980. The Rate of Return to Becoming a Qualified Scientist or Engineer in GreatBritain, 1966-1976. Scottish Journal of Political Economy 27, 41-63. 